\title{
PHYSICIANS' DUAL PRACTICE: A THEORETICAL APPROACH
}

Muruga, K., Vasiljeva, T.

Kirathimo Muruga / RISEBA University of Applied Sciences, Meza iela 3, Riga, Latvia. Email: Kirathimo.Muruga@gmail.com.

Tatjana Vasiljeva / RISEBA University of Applied Sciences, Meza iela 3, Riga, Latvia. Email: Tatjana.vasiljeva@riseba.Iv.

\section{Abstract}

The present study seeks to evaluate the theoretical approach towards physicians' dual practice. This is done by investigating the various theoretical grounds that form the basis of physicians' dual practice. The study presents theoretical findings by comparing them with practical primary data from experienced experts. An in-depth search of the top keywords related to dual practice was done in various databases. The study first identified all articles related to dual practice in various databases. In total, 59,838 articles identified after duplicates were removed were narrowed down to four hundred and thirty-eight (438) studies and considered relevant for review. The filtration process was carried out based on the recentness of the articles. A review of the articles was done to eliminate duplicates, a linguistic check was conducted, and a final sorting was carried out to arrive at fully accessible reviewed articles in the journal databases. Filtration was done to select fully accessible publications under the following keywords: Herzberg's two-factor theory, contract theory, and supply of labour theory. Forty-one (41) fully accessible and peer-reviewed articles were used for analysis. The study underscores that dual practice can be theoretically modelled as a function of three theories (Herzberg's two-factor theory, contract theory, and supply of labour theory). It is paramount, therefore, for studies to appreciate the theories in understanding the motivation behind the dual practice. Thus, the present study has proposed a hybrid integrated theory, the Integrated Theory of Labour, Supply and Motivation, in order to offset the weaknesses of the theories and build on their strengths.

Implications for Central European audience: This study proposes the Integrated Theory of Labour, Supply and Motivation in order to help researchers and government institutions better address the concept of moonlighting in public institutions. The study concludes that future scholars and researchers in related fields could extrapolate the Integrated Theory of Labour, Supply and Motivation by conducting a factor analysis in order to validate the theory since it offers a platform to cover the drivers behind the dual practice in a comprehensive manner and also builds on the strengths of other theories explaining the dual practice. Theoretically, the study also validates the theories it uses and the extent of their applicability to this and similar studies. This is not through ruling out theories explaining dual practice but reinforcing them. The findings of this study may be useful in shaping policy in the area of managing contracts for physicians in dual practice and supply of labour economics in general. 
Keywords: physicians; dual practice; Herzberg's two-factor theory; contract theory; supply of labour theory.

JEL Classification: I15, I18, M14

\section{Introduction}

Dual practice (DP) is the widespread phenomenon of government employees working concurrently both within and outside the public-sector environment. The private work may be undertaken physically within or outside public facilities but is conducted either entirely for personal profit or as a part of a profit-sharing arrangement with the relevant government authority (Hipgrave et al., 2013). Dual practice can likewise be known as dual job holding, moonlighting, multiple job-holding, dual employment, multiple employment, dual working, double work, and pluri-employment (Moghri et al., 2016).

Dual practice, a practice in both the public and private sector, has attracted attention due to fear of a reduced supply of jobs and a shortage of key staff in the public system, a rise in lowpriority services, and conflicts of interest for doctors who may compete for their patients while working for private suppliers (Johannessen \& Hagen, 2014). Brekke and Sørgard (2007) also attributed this to an increase in low-priority treatments and conflicts of interest for physicians who may be competing for their patients when working for private suppliers. One theoretical model has predicted that reduced total health care delivery will result from physicians' dual practice. Doctors' dual practice is a concept used to describe situations where doctors combine work in the public sector with work for private health care providers, education, science, the management or other non-health-related economic activities (Bazyar et al., 2018).

Several reasons for dual practice have been suggested: a wide gap between physicians' income expectations and wages in the public systems, long waiting lists and unsatisfactory working conditions in the public system, and other factors reflecting individual choices. The reasons for dual practice may be quite diverse at the individual level, and an analysis of dual practice should recognise that individual employees might have quite different expectations and personal career goals (García-Prado \& González, 2011).

Alaref et al. (2017) drew on existing theoretical evidence on dual practice, along with economic theory related to labour market dynamics and health worker motivation, to understand the determinants and underlying causes of dual practice in Palestine, how to design a policy to maximise health worker motivation and adherence to rules under these conditions, and what consequences of these policies can be expected. These factors, among others, were associated with working conditions, pay and remuneration, as well as working hours. A study by Ashmore and Gilson (2015) bases its argument on organisational theory as well as various theories of economics to explain organisational functioning and behaviour. In organisational theory, the concepts of 'motivation', 'job satisfaction and 'loyalty' have commonly been used to understand a variety of workplace decisions. Motivation, adopted by some researchers in the health systems literature, refers to an "individual's degree of willingness to exert and maintain an effort towards organisational goals" (Mbindyo et al., 2009). 
Countries that attempted total banning of dual practice, such as Portugal and Greece, could not easily stamp it out since it did not prevent public doctors from practising privately (Mossialos et al., 2005). The failure has been attributed to a lack of capacity to enforce it. Meanwhile, in low and middle-income countries (LMICs), salaries and income play a vital role: health workers are underpaid, and members of the general population are willing to pay for more convenient and possibly better services (Kiwanuka et al., 2011).

In a theoretical model of what Russo et al. (2013) categorised as the 'within' model, Russo et al. (2013) showed that in the organisation of a hospital's public and 'on payment services, equity enhancement and equity reduction may be the ultimate outcomes, depending on whether hospitals maximise profit or revenue and on the interrelationships between demand functions for different services. A similar analysis could be applied to the individual physician's decision to allocate effort across two services - public and private provision - and may also identify equity enhancing and equity reducing scenarios. Government attempts to regulate dual practice in low-income contexts will have to consider this added complexity, which is consistent with some of the existing literature on this subject (González \& Macho-Stadler, 2013).

It appears that retention of specialists in public hospitals may not be possible only by implementing laws and regulations, i.e. without considering other factors, including rivalry from the private sector in recruiting experienced and senior public sector physicians. Implementation of financial and non-financial incentives and facilities may be an effective mechanism to retain specialists in the public sector full-time; even with the existence of complete restriction laws, a significant proportion of physicians still engage in DP (Bayat et al., 2018).

Thus, dual practice must be based on theoretical grounds that can offer solid reasoning for the ultimate causes and motivators of dual practice. Upon such grounds, the health sector may be better informed of the existing problem and devise better strategies to manage dual practise (given its serious impact, especially on the government/public hospitals). Therefore, the present study seeks to deduce a better theoretical approach towards the process.

The dual practice has been posited as an influence on both the workload and attractiveness of a given institution, and in the public health sector, it has been shown to pose threats to the efficiency, quality and equity of health services (Kiwanuka et al., 2011). The practice has traditionally been treated with suspicion by the public health and health system research literature amid fears that it may compromise the supply of public services (Brekke \& Sørgard, 2007). There is a concern among policymakers and patients alike that multiple job holding in both the public and private sector jeopardises the availability of professionals and the quality of services in the public sector and diverts patients towards costlier private care, therefore putting at risk the attainment of universal health coverage (UHC) goals (Russo et al., 2018).

It has been noted that dual practice has not received much empirical focus and attention. There exists a difference in the perspectives drawn from different theoretical foundations by many scholars. For instance, Gray (2019) investigates how Australian dual registrants identified as midwives to meet national registration-renewal requirements based on the theory of categorisation. However, the study was not clear on how the factors (especially the motivation behind the practice) that lead to dual practice draw from theory. Lambrou et al. (2010) draw from Aldersfer's theory, Herzberg's two-factor theory, and McClelland's acquired 
needs theory as well as Maslow's hierarchy of needs theory in order to validate the instrument regarding the motivational factors under investigation: job attributes, remuneration, coworkers and achievements. However, despite applying Herzberg's two-factor theory, the study failed to address the extrinsic factors and only addressed the intrinsic, that is, motivation factors. Dickey et al. (2015) applied the Lancaster characteristic theory of value and random utility theory in explaining the trigger behind multiple job holding. Based on the theory, the study found that individuals are motivated by financial constraints, and they are attracted to second jobs that allow them to develop new skills, which they may later use to move to a different career pathway. This theory finds relevance in focus on dual practice. Generally, the impact of dual practice remains an open question that warrants more attention from researchers and policymakers alike (García-Prado \& González, 2011).

This study thus notes that there are many approaches to dual practise but no clear theory that has been used to validate the reasons as intrinsic and extrinsic factors behind physicians holding multiple jobs in the health sector. It is, thus, worthwhile for the present study to extrapolate the subject based on theory in the Kenyan context. The study proposes the Integrated Theory of Labour, Supply and Motivation towards dual practice.

\section{Theoretical background}

\subsection{Herzberg's two-factor theory}

This is one of the needs-based theories, which also include Maslow's hierarchy of needs theory, Alderfer's theory, and McClelland's acquired needs theory (Lambrou et al., 2010). Herzberg's two-factor theory was developed by a psychologist, Frederick Herzberg, whose interest was in correlating the relationship between workplace motivations and employee attitude (Herzberg et al., 1966). The main idea behind this theory is to discover the reason why employees are either satisfied or unsatisfied on the job. The two-factor theory assumes that there are two sets of factors that influence motivation in the workplace by either enhancing employee satisfaction or hindering it (Hackman \& Oldham, 1976). These include the presence of motivators (intrinsic factors) or the absence of hygiene factors (extrinsic factors). The absence of hygiene factors will cause employees to work less hard. Hygiene factors are not present in the actual job itself but surround the job. Hygiene was used to describe the factors that cause dissatisfaction. The presence of motivators causes employees to work harder. They are found within the actual job itself (Riley, 2005).

According to the theory, motivating factors such as achievement, recognition, the work itself, responsibility, advancement and growth can be applied to boost the zeal and motivation of employees to work (Hackman \& Oldham, 1976). With regard to hygiene, Alshmemri et al. (2017) proposed applying the following to improve the satisfaction of employees: fair and clear company policies; supervision; healthy, amiable, and appropriate relationships; safe and better work conditions; salary; status; and security. Just like the hierarchy theory of needs (Maslow, 1943), this theory also lists the motivators in order of importance (company policy, supervision, employee's relationship with their boss, work conditions, salary, and relationships with peers).

The hygiene factors, when absent, can lead to dissatisfaction in the workplace but, when fully catered for in the work environment, are not sufficient on their own to satisfy workers, whereas the motivators referring to the nature of the job provide satisfaction and lead to higher 
motivation (Dartey-Baah \& Amoako, 2011). Likewise, Riley (2005) proposed that managers need to understand and choose styles at the workplace that will be effective in ensuring that there is minimal friction between employees. The two sets of factors need to be integrated to increase employees' performance or productivity.

According to Yusoff et al. (2013), there is an added advantage of using Herzberg's two-factor theory since it provides an integration of individuals' intrinsic and extrinsic motivation factors that can ideally cover other motivation theories. Motivation and hygiene factors introduced by Herzberg have found similarities among other motivation theories under content theories as each theory addresses various employees' needs for motivation in similar terms.

Furthermore, responsibilities, achievements, growth, promotion, recognition and work itself (as Herzberg's motivational factors that contribute to dual practice) are based on Maslow's theory of self-actualisation and self-esteem (Maslow, 1943) and McClelland's theory of need for achievement (McClelland, 1965). Relationship with peers, personal life, and supervision, categorised under Herzberg's hygiene factors, are consistent with Maslow's belongingness, Alderfer's relatedness need, and McClelland's need for affiliation. As to results, compared to the other motivational theories, the two-factor theory provides more comprehensive sets of factors that cover basic individual internal and external needs to put additional effort into jobs.

Another basic factor of job satisfaction and employee performance (job security) was analysed by Danish and Usman (2010), and the direct correlation between job safety and job satisfaction of employees was verified. The Malaysian research conducted by Islam and Ismail (2008) also concluded that the job security aspect had a positive, motivating impact on their respondents. According to Lambrou et al. (2010), in a study investigating medical and nursing staff of the largest public hospital in Cyprus, four specific motivation factors were grounded on Maslow's needs theory and Herzberg's two-factor theory. These are:

- Job attributes

- Remuneration

- Co-workers

- Achievements

The survey revealed that achievements were ranked first among the four main motivators, followed by remuneration, co-workers and job attributes. Achievements, which is an intrinsic factor, was the main motivator in both the doctor and nurse subgroups. It can be shown that the theory is relevant in addressing both the intrinsic and extrinsic factors of the organisation.

\subsection{Contract theory}

This is an economic theory that studies how economic actors can and do construct contractual arrangements, generally in the presence of asymmetric information (Hart \& Holmström, 1987; Bolton \& Dewatripont, 2005). Contract theory is often classified within the area known as business and economics due to its links with both organisations and rewards. The development of optimal management compensation systems is a popular application of it. The first formal treatment of this subject was given in the 1960s by Kenneth Arrow in the field of economics (Hart \& Holmström, 1987). Contract theory also utilises the notion of a complete contract, which is thought of as a contract that specifies the legal consequences of every possible state of the world. A more recent development known as the theory of incomplete contracts, pioneered by Oliver Hart and his co-authors, studies the incentive 
effects of parties' inability to write complete contingent contracts, e.g. concerning relationshipspecific investments (Fleckinger \& Martimort, 2018).

There are many applications of contract theory, among which the following are important: labour contracts, regulation, price discrimination, financial contracts, and others. A leading application of the incomplete contracting paradigm is the Grossman-Hart-Moore property rights approach to the theory of the firm (Hart \& Holmström, 1987). This theory has a direct link to the principal-agent theory of the firm, that is, agency theory (Jensen \& Meckling, 1976). A basic premise of organisation theory is that managers who are obligated to operate in the interest of investors are also self-interested and reluctant to forfeit their advantages for the premiums of the shareholders. Ross (1973) and Mitnick (1975) have shaped this hypothesis and come up with two unique methodologies in their respective works. Ross viewed the organisation issue as an issue of motivations, while Mitnick believed the issue happens because of the institutional structure, yet the basis of their hypotheses is comparative.

Thus, based on the backdrop of contract theory in conjunction with the theory of the firm, Kantarevic and Kralj (2016) developed a stylised principal-agent model with moral hazard and adverse selection to provide a unified framework for understanding some of the most salient features of the recent physician payment reform in Ontario and its impact on physician behaviour. They looked at why physicians choose a payment contract from a menu that includes an enhanced fee-for-service contract and a blended capitation contract, as well as why the capitation rate is higher, and the cost reimbursement rate is lower in the blended capitation contract. Besides, the study was aimed at determining why physicians sort selectively into the contracts based on their preferences and why physicians in the blended capitation model provide fewer services than physicians in the enhanced fee-for-service model (dual practice).

Alaref et al. (2017) drew on theoretical evidence on dual practice, along with economic theory related to labour market dynamics and health worker motivation, to understand the determinants and underlying causes of dual practice in Palestine, how to design a policy to maximise health worker motivation and adherence to rules under these conditions, and what consequences of these policies can be expected.

Fichera and Pezzino (2017) relied on contract theory to determine the relationship between pay for performance and the contractual choice of general practitioners in England. Thus, from their analysis, the study validated that financial incentives are enough to change behaviour and to achieve targets. The findings suggested that it is not necessary to align targets to professional priorities and values to obtain behaviour change, although doing so enhances enthusiasm and understanding. Participants agreed that the aims of the pay-forperformance scheme had been met in terms of improvements in disease-specific processes of patient care and physician income as well as improved data capture.

Performance-based contracting (PBC) as well as Payment by Results (PBR), according to Jiang et al. (2012), largely hinged on the principal-agent theory to address the optimal contracting problem where a service purchaser (the principal) minimises his/her cost of purchasing the services and achieves the performance target (a waiting-time target) while taking into account the response of the provider (the agent) to the contract terms. Given the incentives offered by the contract, the provider maximises his payoff by allocating his outpatient service capacity among three patient groups: urgent patients, dedicated advance 
patients, and flexible advanced patients. The analysis brings out significant insights, that is, when the agent's capacity allocation decisions are observable and contractible, the performance-based contracting (PBC) and Payment by Results (PbR) approaches to produce the same outcomes, irrespective of whether the information setting is symmetric or asymmetric. However, if the agent's decisions are not observable and contractible, PBC outperforms $\mathrm{PbR}$, thus prompting the need for the dual practice among the service providers. This suggests that performance-related incentives should be incorporated into service procurement contracts.

Importantly, however, job satisfaction and loyalty are two parts of a more complex staying/leaving decision process (Locke, 1976; Spector, 1997). Mobley (1977) expanded upon this through his review of the organisational literature. He constructed a model where an employee's evaluation of their job, based around their expectations and values being unmet, leads them to be dissatisfied. Mobley stressed that workers then evaluate the costs and benefits of quitting, search for and compare alternative job options, and only then decide to stay or leave. There is also the possibility that workers act 'impulsively' about retention decisions. These latter steps in the causative model, impulsive or not, occur after the variable 'intention to stay'. Intention to stay is the most proximate predictor of retention this paper deals with since retention itself could not be observed during research due to the crosssectional and self-reported nature of the qualitative study.

\subsection{Supply of labour theory}

Supply is the number of goods or the service an economic individual offers to sell in the market at a given price. The theory of supply states that with an increase in price, the number of goods the economic individual wishes to supply will also increase (Ehrenberg \& Smith, 2016). Supply of labour draws from labour economics, which seeks to understand how suppliers of labour services (workers) respond to the demanders of labour services (employers) given the pattern of wages, employment, and income (Ehrenberg \& Smith, 2016). Supply of labour theory is an economic theory developed by John Maynard Keynes (Keynes, 1937).

According to Keynes (1937), the problem of the relation of wages to employment is certainly a function of money and prices proposed in the quantity theory of money (popularly stated in the equation of exchange: $M V=P Y$, where $M$ is the money supply, $V$ is the velocity of money, $P$ is the price level and $Y$ is the real GDP). Here, as the supply increases in the market, the price will tend to drop, and as demand increases, the price will tend to increase, while as the demand decreases, the price will also tend to decrease. Thus, the labour supply states that as the demand for labour increases, the wages tend to drop and vice versa. According to Marx (1972), the working class is exploited under capitalism (an economic and political system in which a country's trade and industry are controlled by private owners for profit, rather than by the state) and devaluates the wage rate and value.

Socha and Bech (2011), in support of the theory, conducted a theoretical analysis of physicians' dual practice and indicated both its positive and negative effects. Some of the effects depend, however, on assumptions that are undermined in the broader literature. The analysis assumes that dual practitioners' objective is to maximise income. Yet, while physicians seem to engage in private practice on top of a public one mainly to increase income, it remains uncertain whether the dual practice is an income-maximising combination 
of jobs. Moreover, the costs of enforcing restrictions on dual practice are rarely considered. According to Johannessen and Hagen (2014), economic factors followed by family variables are significant elements influencing dual practice. Although their findings indicate that engagement in dual practice by public hospital physicians in a well-regulated market may increase the total labour supply, this may vary significantly between medical specialities.

Chen et al. (2016) conducted a study to determine people's current perception of dual practice with respect to two sides: the supply side (regarding medical staff) and the demand side (concerning outpatients). The study validated that, theoretically, both medical staff and outpatients supported the implementation of dual practice and believed that the policy would reduce the difficulty in consulting a doctor. Besides, medical staff who held the belief that dual practise could reduce the difficulty in consulting a doctor were more willing to participate in dual practice. This is an indication that the practice is a derivative of the supply-demand model.

\section{Methodology}

\subsection{Pre-research}

The study adopted the desktop literature review method (desk study). This involved an indepth review of studies related to physicians' dual practice. An in-depth search of the top keywords related to dual practice was done in various databases. The authors looked into various theories used by various studies to explain the reasons behind the dual practice. Thus, the study was purely qualitative, drawing its findings from secondary sources of data.

A grey literature search plan was developed to incorporate four different searching strategies: pre-research, identification process, the extraction process, filtration Process and synthesis. This was important because: some databases did not comprehensively index all information in journal issues; the researcher was able to scan content quickly for relevant studies from high-impact journals and ensure that relevant studies were not overlooked. However, Since Gray literature is written informally or non-commercially or stays unpublished, it is typically literature that is not peer reviewed, but can also be strong credible material. This will also be useful for your study. It is generated from a number of sources and is typically not categorised or structured, thus making it difficult to find (Godin et al., 2015; Paez, 2017).

\section{Accumulating the source literature by different techniques}

Two sorting stages were followed:

\section{Identification and search process}

This is the first stage, which comprised the initial identification of all articles that were based on dual practice in various databases. The first search was done generally by searching for articles according to the article title, abstract, and keywords. This was aided by snowballing technique, where studies led to a roadmap in identifying similar studies in the searching process. In addition, a page-by-page grey literature examination of relevant journal issues, reference lists, conference proceedings and other publications for relevant studies was done in line with the top keywords (Herzberg's two-factor theory, contract theory and supply of labour theory) under investigation. The identification and search arrived at 5,659,407 articles in total, where 59,838 were identified after duplicates were removed. 
Figure 1 | Filtration process
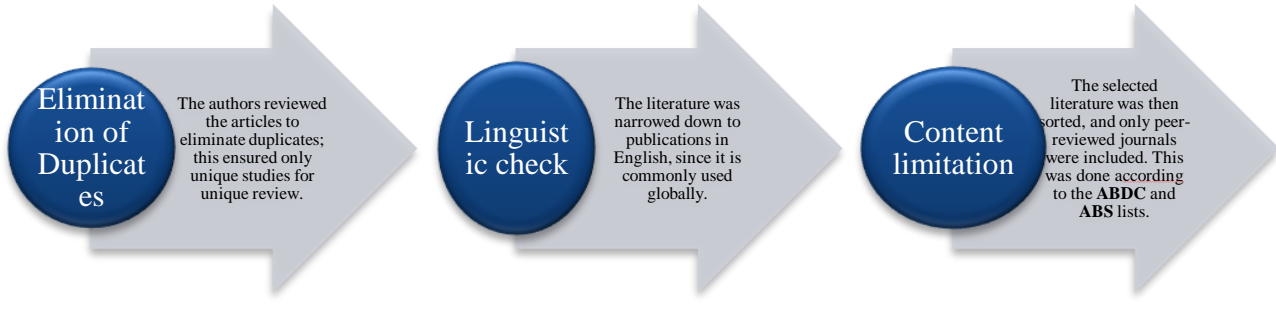

Source: authors

The filtration process was done based on the recentness of the articles. This section describes the process that the study followed in analysing the literature. The authors reviewed the articles to eliminate duplicates; this ensured unique studies for unique review. The literature was narrowed down to publications in English since it is commonly used globally. Studies in other languages that required translation were dropped. The selected literature was then finally sorted, and only peer-reviewed articles in the journal databases were included. The study filtration, therefore, arrived at two thousand and nine fully screened articles.

\section{Extraction}

Extraction then proceeded to extract (from the screened articles) those articles that were available for meta-analysis. The search involved fully available publications about physicians' DP. A total of four hundred and thirty-eight (438) studies were found and considered relevant for review. This process is described in the table below:

Table 1 | Extraction process

\begin{tabular}{|c|c|c|c|c|c|c|c|c|}
\hline \multirow[b]{2}{*}{ Database } & \multicolumn{3}{|c|}{$\begin{array}{l}\text { First search - general search according } \\
\text { to the article title, abstract, keywords }\end{array}$} & \multirow[b]{2}{*}{$\begin{array}{c}\begin{array}{c}\text { Total } \\
\left(1^{\text {st }}\right. \\
\text { search })\end{array} \\
\end{array}$} & \multicolumn{3}{|c|}{$\begin{array}{l}\text { Second search - fully available } \\
\text { publications }\end{array}$} & \multirow[b]{2}{*}{$\begin{array}{c}\text { Total } \\
\left(2^{\text {nd }}\right. \\
\text { search }\end{array}$} \\
\hline & $\begin{array}{c}\text { Herzberg's } \\
\text { two-factor } \\
\text { theory }\end{array}$ & $\begin{array}{c}\text { Contract } \\
\text { theory }\end{array}$ & $\begin{array}{l}\text { Supply of } \\
\text { labour } \\
\text { theory }\end{array}$ & & $\begin{array}{c}\text { Herzberg's } \\
\text { two-factor } \\
\text { theory }\end{array}$ & $\begin{array}{c}\text { Contract } \\
\text { theory }\end{array}$ & $\begin{array}{l}\text { Supply of } \\
\text { labour } \\
\text { theory }\end{array}$ & \\
\hline $\begin{array}{l}\text { ScOPUS } \\
\text { Science }\end{array}$ & 5.5 & $N / A$ & $\mathrm{~N} / \mathrm{A}$ & & $N / A$ & $\mathrm{~N} / \mathrm{A}$ & N/A & 0 \\
\hline Direct & 7,521 & 9,841 & 3,953 & 21,315 & 59 & 30 & 40 & 129 \\
\hline EBSCO & 15 & 270 & 1 & 286 & 5 & 62 & 1 & 68 \\
\hline
\end{tabular}




\begin{tabular}{|c|c|c|c|c|c|c|c|c|}
\hline SAGE & & & & & & & & \\
\hline $\begin{array}{l}\text { Journals } \\
\text { Google }\end{array}$ & 1,499 & 108,051 & 59,055 & 168,605 & 16 & 116 & 17 & 149 \\
\hline $\begin{array}{l}\text { Scholar } \\
\text { Emerald }\end{array}$ & 18,900 & $3,130,000$ & $2,250,000$ & $5,398,900$ & $\mathrm{~N} / \mathrm{A}$ & $\mathrm{N} / \mathrm{A}$ & $\mathrm{N} / \mathrm{A}$ & 0 \\
\hline Insight & 301 & 45,000 & 25,000 & 70,301 & 5 & 55 & 32 & 92 \\
\hline Total & 28,236 & $3,293,162$ & $2,338,009$ & $5,659,407$ & 85 & 263 & 90 & 438 \\
\hline
\end{tabular}

Source: field data gathered by the authors on 30 August 2019

Table 2 | Extraction table

\begin{tabular}{|c|c|c|c|}
\hline \multirow[b]{2}{*}{ Technique } & \multicolumn{2}{|c|}{ Articles } & \multirow[b]{2}{*}{ Author and year of publication } \\
\hline & No. & $\%$ & \\
\hline Case study & 2 & 2.8 & Paina et al. (2014), Martinez Jr et al., (2014). \\
\hline $\begin{array}{l}\text { cross-sectional } \\
\text { design }\end{array}$ & 11 & 15.3 & $\begin{array}{l}\text { Ojakaa et al. (2014), Goetz et al. (2016), Miotto et al. (2018), Gacevic et al. (2018) and Kottwitz } \\
\text { et al. (2017). }\end{array}$ \\
\hline $\begin{array}{l}\text { Descriptive } \\
\text { research }\end{array}$ & 23 & 31.9 & $\begin{array}{l}\text { Moghri et al. (2016), Adisa et al. (2017), Strouwen et al. (2019), Karakolias et al. (2017) and } \\
\text { Bayat et al. (2018). }\end{array}$ \\
\hline $\begin{array}{l}\text { Experimental } \\
\text { design. }\end{array}$ & 6 & 8.3 & Purcell et al. (2019), Jansen et al. (2016) and Kalb et al. (2018) \\
\hline $\begin{array}{l}\text { Linear multiple } \\
\text { regression }\end{array}$ & 3 & 4.2 & Fichera and Pezzino (2017), Johannessen and Hagen (2014) and Gonzalez et al. (2018) \\
\hline $\begin{array}{l}\text { Logit, probit, } \\
\text { tobit model }\end{array}$ & 1 & 1.4 & Kusi, G. (2018) \\
\hline $\begin{array}{l}\text { longitudinal } \\
\text { design }\end{array}$ & 8 & 11.1 & Hirsch et al. (2016), Panos et al. (2014), Bruns and Pilkauskas (2019) and Gray, M. (2019). \\
\hline Mix & 3 & 4.2 & Russo et al. (2013), \\
\hline Others & 15 & 20.8 & Wombacher and Felfe (2017), Russo et al. (2018) \\
\hline Grand Total & 72 & 100 & \\
\hline
\end{tabular}

Source: authors

\section{Analysis}

After the filtration was done, the third step involved the selection of fully accessible publications. The reduction of the literature to only fully accessible publications yielded specificity and allowed the authors to focus on articles related to Herzberg's two-factor theory, contract theory and supply of labour theory. After a full in-depth assessment of the top keywords (Herzberg's two-factor theory, contract theory and supply of labour theory), the authors arrived at 41 fully accessible and peer-reviewed articles that were suitable for analysis. The analysis was done using Excel, and the findings were presented in the form of figures and tables. 
Figure 2 | The PRISMA flow-chart for a review update with previously included studies incorporated into the results of an updated literature search

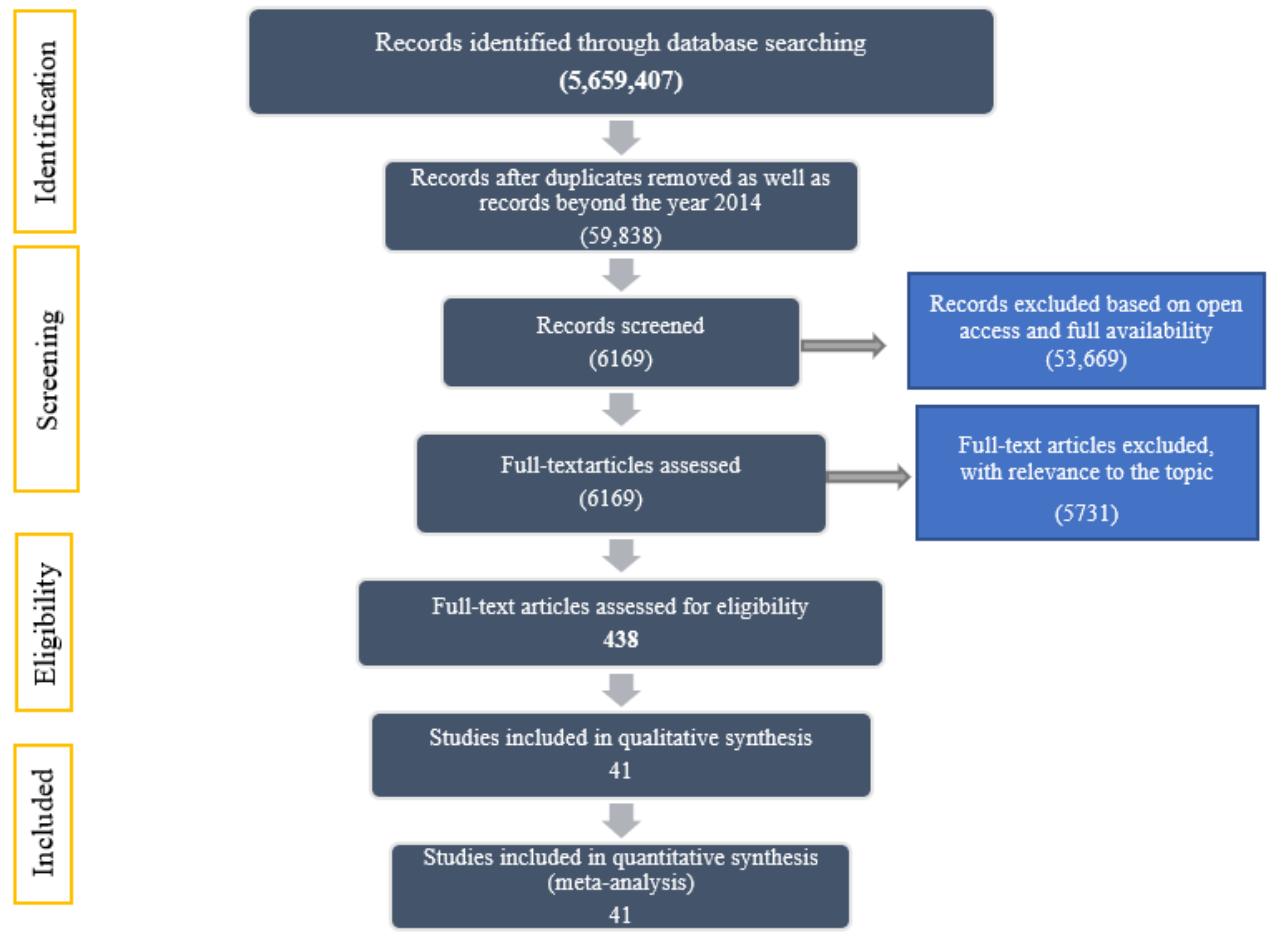

Source: authors

\section{Findings}

Table 2 shows that the majority of the studies (93\%) reviewed were sourced from peerreviewed journals, while $7 \%$ were sourced from doctoral dissertations. This implies that none of the articles was unreliable, and since the majority were peer-reviewed articles, the present study finds solid grounds to back the theoretical review.

Table 3 | The top sources of theoretical research

\begin{tabular}{l|c|c}
\hline Type of Source & Number of articles & Percentage \\
\hline Doctoral dissertation & 3 & $7 \%$ \\
Peer-reviewed journal & 38 & $93 \%$ \\
\hline Total & 41 & $\mathbf{1 0 0}$ \\
\hline
\end{tabular}

Source: authors

Figure 3 indicates that 21 empirical studies (51\%) appreciated the use of motivation theories in explaining the dual practice, eleven $(27 \%)$ of them acknowledged that labour supply theory was useful in explaining the dual practice, and $9(22 \%)$ of them incorporated contract theory. This implies that dual practice has gained prominence in various contexts, and motivational factors are at the forefront in motivating physicians toward the practice. Theoretically, the present study finds concrete grounds on which to base these arguments and, thus, it is 
worthwhile for dual practice to be studied regarding motivational theories accompanied by labour supply theory as well as contract theory.

\section{Figure 3 | Top keywords}

Theoretical Keywords

25

20

15

15

9

11

10

0

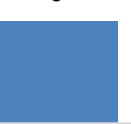

Contract Theory

Labour Supply Theory

Motivation Theory

\section{Source: authors}

The findings in Figure 4 indicate that the application of Herzberg's two-factor theory as a motivational factor has experienced an upward trend since the year 2004. This implies that the theory has relevance in the field, especially when discussing matters of physicians' dual practise in the health sector. These findings have shown that the majority of the studies surveyed (11) trended between 2016 and 2019. Thus, the application of the theory is found to be relevant for extrapolation.

\section{Figure 4 | Herzberg's Two-Factor Theory}

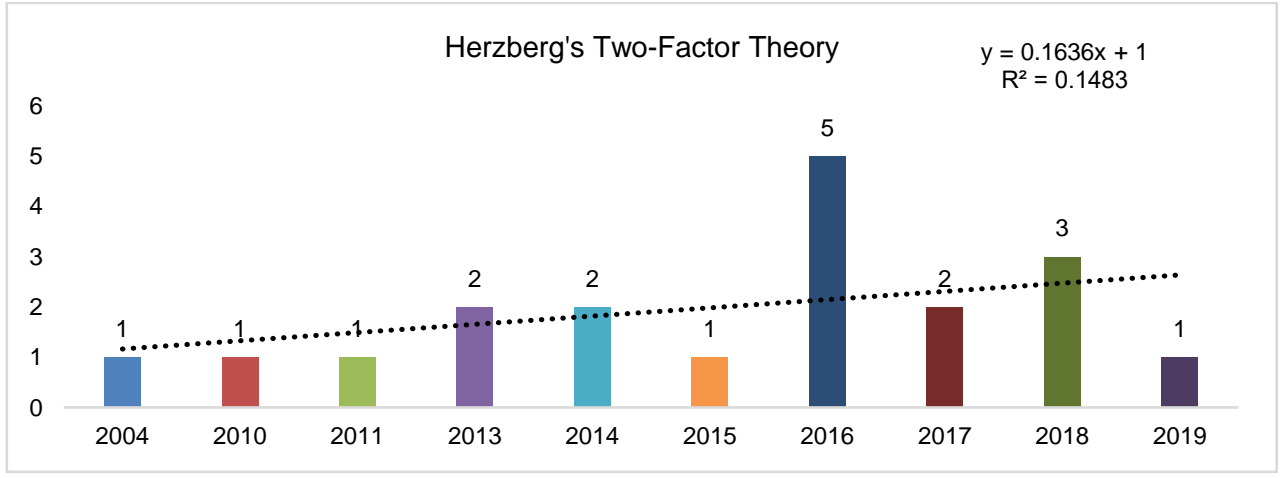

Source: authors

Furthermore, the findings on contract theory indicate that scholars and studies have acknowledged its application, with two studies in the years 2012 and 2019, respectively. In general, the findings indicate that there has been a slight increase in the use of the theory, which is represented by a positive coefficient of 0.0857 . Thus, the application of the theory is found to be relevant for extrapolation.

Figure 5 | Contract theory 
Contract Theory

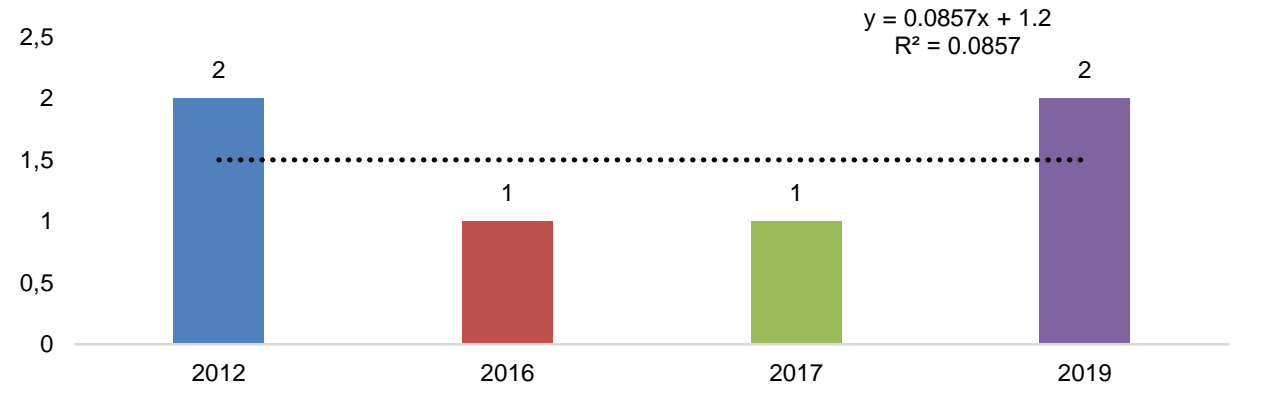

Source: authors

Figure 6 | Labour supply theory

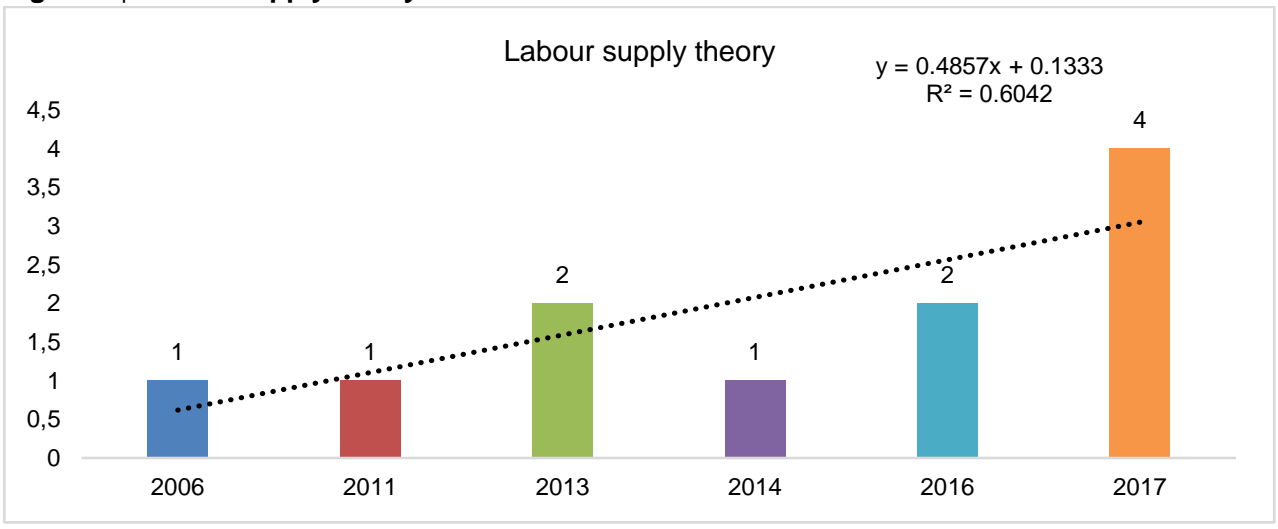

Source: authors

The findings of the study indicate that the supply of labour theory has been on the rise (supported by a steep gradient of 0.4857 ). Also, the theory peaked in the year 2017 , where it was found that 4 of the studies appreciated the use of the theory. This implies that the supply of labour theory as a function of the economy is a relevant factor that many studies have acknowledged as affecting the supply of physicians even in the health sector. This is solidly grounded on the motivation of wages, which translates to the income for which physicians are willing to supply their services. Therefore, the supply of labour theory cannot be overemphasised in the present study.

\section{The Integrated theory of labour, supply and motivation}

Thus, based on the above theoretical findings, the study proposes the incorporation of the Integrated Theory of Labour, Supply and Motivation in addressing dual practice since it is a derivative of motivational factors, which range from intrinsic to extrinsic factors. This indicates that dual practice is largely motivated by factors that the physicians believe to be of value to their workmanship. For instance, they are motivated by low payment procedures in governmental hospitals to seek alternative supplementary income from the services they offer in private hospitals. In addition, they will be discouraged by the unbinding legal contracts and unimplemented policies set by the government regarding their services. Furthermore, macroeconomic conditions have been attributed to contributing to this in that the supply of 
labour is a derivative of the wage rate. Thus, if the wage rate is too low, this will decrease the number of physicians willing to offer their medical services at the set prices.

Finally, this study underscores that dual practice can be theoretically modelled as a function of three theories (Herzberg's two-factor theory, contract theory and supply of labour theory). It is paramount, therefore, for studies to appreciate the theories in understanding the motivation behind the dual practice. Thus, for future studies, the present study recommends the incorporation of the Integrated Theory of Labour, Supply and Motivation for a better and clearer understanding of the dual practice. The researcher, therefore, concludes that the creation of the "integrated theory" is useful in helping other future studies in the related field. This theory has been extrapolated based on:

- Well-grounded synthesis of theoretical findings.

- Various particular theories related to this area what the author is going to use as the theoretical framework of the research.

- The practical experience of highly qualified experts from the industry.

This new "integrated theory" is set to give the basis for the perfect understanding of the "physicians dual practice" phenomenon.

\section{Discussion}

Evidence has been shown from the literature that a review of dual practice is of significance, especially in the health sector. The abovementioned theories have gained in prevalence in the period under review, and it can be concluded that dual practice is a function/derivative of various motivators (mentioned in various theoretical backgrounds) such as achievement, recognition, the work itself, responsibility, advancement, company policy, supervision, employee's relationship with their boss, work conditions, salary, and relationships with peers. These factors have been drawn predominantly from Herzberg's two-factor theory, Maslow's hierarchy of needs theory, Alderfer's theory, and McClelland's acquired needs theory. Contract theory contributes to the theories by linking the two parties together through a contract that is agreeable under the set terms and conditions.

According to the developer of the theory, Hart and Holmström (1987), contract theory's main responsibility is to introduce and inform labour contracts, regulation, price discrimination, and financial contracts, among other things. In conjunction with the principal-agent theory of the firm, that is, agency theory (Jensen \& Meckling, 1976), managers who are obligated to operate in the interest of investors have an obligation (self-interested and reluctantly) to follow or forfeit their advantages for the premiums of the shareholders. Therefore, the study finds that the elements of contract theory become relevant between the service provider (physician) and the public sector (public hospital) under legally binding terms against which the two parties face the consequences if violated. It can be seen that job satisfaction and loyalty are the main drivers under this theory, where they influence the staying/leaving decision process (Locke, 1976; Spector, 1997). This can be noted where an employee's evaluation of their job, based around their expectations and values being unmet, leads them to be dissatisfied. Mobley stressed that workers then evaluate the costs and benefits of quitting, search for and compare alternative job options, and only then decide to stay or leave.

The supply of labour theory capitalises on labour economics, which maintains that the suppliers of labour services (physicians) will respond to the demanders of labour services 
(employers) given the pattern of wages, employment, and income (Ehrenberg \& Smith, 2016). This theory has been seen to complement the tenets of Herzberg's two-factor theory by taking into account the motivators of the dual practice. It can be seen that physicians are influenced by the practice, given the prices set for their services in the industry. Thus, if properly and adequately paid, physicians will be willing to offer their expertise/services to their employers. This is a form of a contract-based pay system that is legally binding and provides the security of terms of service to both parties. Therefore, the present study finds that it is worthwhile to integrate the three theories into one theory that is capable of addressing all the facets of dual practice.

\section{Conclusions and implications}

Based on the abovementioned theories (Herzberg's two-factor theory, motivational theory, contract theory, the supply of labour theory), the study proposed the Integrated Theory of Labour, Supply and Motivation, which combines the three main aspects affecting dual practice. The study concludes that rewards, the supply of labour and labour contracts work hand in hand in influencing physicians towards dual practice.

These theories offer a solid ground for researchers to build theoretical concepts that explain the dual practice. They likewise aptly explain the concept of dual practice and the motivators that lead physicians to engage in the dual practice. This is because the theories have been acknowledged by many authors in various contexts, including the health sector. For instance, the concept of pay and rewards, which is grounded on the wages and allowances of physicians, still forms a major component of the economy by influencing the supply of not only physicians' labour but also labour in general. However, the study has found that the application of one theory at a time is a limiting factor due to the weaknesses of some theories in certain concepts and contexts. In addition, it has been noted that the proportion of physicians engaging in dual work declined by one third, as indicated by Johannessen (2014). This shows that dual practice is dependent on the contract that binds physicians to the working environment along with the wages that are attached to the contract.

Thus, the present study has proposed a hybrid integrated theory, the Integrated Theory of Labour, Supply and Motivation, to offset the weaknesses of the theories and build on their strengths. The study likewise concludes that future scholars and researchers in related fields could extrapolate the Integrated Theory of Labour, Supply and Motivation by conducting a factor analysis to validate the theory.

Therefore, this study recommends that authors who carry out future studies on dual practice should incorporate the Integrated Theory of Labour, Supply and Motivation since it offers a platform to cover the drivers behind the dual practice in a comprehensive manner and builds on the strengths of other theories explaining the dual practice. Thus, for future studies, the present study recommends the incorporation of the Integrated Theory of Labour, Supply and Motivation for a better and clearer understanding of the dual practice.

This study, therefore, proves to be a vital study that other authors from Sub-Saharan Africa can use to base future studies on. Theoretically, the study also validates the theories it uses and the extent of their applicability in this and similar studies. This is not through ruling out theories explaining dual practice but reinforcing them. The findings of this study may be useful 
in shaping policy in the area of managing contracts for physicians in dual practice and supply of labour economics in general.

\section{Acknowledgement}

I acknowledge the continued guidance and support from the supervisor and Vice-Rector for Research "RISEBA" University of Business, Art and Technology, Professor, Dr. oec.Tatjana Vasiljeva.

\section{References}

Adisa, T. A., Mordi, C., \& Osabutey, E. L. (2017). Exploring the implications of the influence of organisational culture on work-life balance practices. Personnel Review.

Alaref, J., Awwad, J., Araujo, E., Lemiere, C., Hillis, S. A., \& Özaltin, E. (2017). To ban or not to ban? Regulating dual practice in Palestine. Health Systems \& Reform, 3(1), 42-55.

Alshmemri, M., Shahwan-Akl, L., \& Maude, P. (2017). Herzberg's two-factor theory. Life Science Journal, 14(5), 12-16.

Ashmore, J., \& Gilson, L. (2015). Conceptualising the impacts of dual practice on the retention of public sector specialists - evidence from South Africa. Human Resources for Health, 13(1), 3.

Bayat, M., Zalani, G. S., Harirchi, I., Shokri, A., Mirbahaeddin, E., Khalilnezhad, R., ... \& Akbari-Sari, A. (2018). Extent and nature of dual practice engagement among Iran medical specialists. Human resources for health, 16(1), 1-10.

Bazyar, M., Rashidian, A., Jahanmehr, N., Behzadi, F., Moghri, J., \& Doshmangir, L. (2018). Prohibiting physicians' dual practice in Iran: Policy options for implementation. The International Journal of Health Planning and Management, 33(3), e711-e720.

Bolton, P., \& Dewatripont, M. (2005). Contract theory. MIT press.

Brekke, K. R., \& Sørgard, L. (2007). Public versus private health care in a national health service. Health Economics, 16(6), 579-601.

Bruns, A., \& Pilkauskas, N. (2019). Multiple job holding and mental health among low-income mothers. Women's Health Issues, 29(3), 205-212.

Danish, R. Q., \& Usman, A. (2010). Impact of reward and recognition on job satisfaction and motivation: An empirical study from Pakistan. International journal of business and management, 5(2), 159.

Dartey-Baah, K., \& Amoako, G. K. (2011). Application of Frederick Herzberg's Two-Factor theory in assessing and understanding employee motivation at work: a Ghanaian Perspective. European Journal of Business and Management, 3(9), 1-8.

Dickey, H. S., Watson, V., \& Zangelidis, A. (2015). What Triggers Multiple Job-Holding?: A Stated Preference Investigation.

Ehrenberg, R. G., \& Smith, R. S. (2016). Modern labour economics: Theory and public policy. Routledge.

Fichera, E., \& Pezzino, M. (2017). Pay for performance and contractual choice: the case of general practitioners in England. Health Economics Review, 7(1), 1-14.

Fleckinger, P., \& Martimort, D. (2018). Contract Theory in the Spotlight: Oliver Hart and Bengt Holmström, 2016 Nobel Prize Winners. Revue d'économie politique, 128(4), 493-533. 
Gacevic, M., Milicevic, M. S., Vasic, M., Horozovic, V., Milicevic, M., \& Milic, N. (2018). The relationship between dual practice, intention to work abroad and job satisfaction: A population-based study in the Serbian public healthcare sector. Health Policy, 122(10), 1132-1139.

García-Prado, A., \& González, P. (2011). Whom do physicians work for? An analysis of dual practice in the health sector. Journal of Health Politics, Policy and Law, 36(2), 265-294.

Godin, K., Stapleton, J., Kirkpatrick, S. I., Hanning, R. M., \& Leatherdale, S. T. (2015). Applying systematic review search methods to the grey literature: a case study examining guidelines for school-based breakfast programs in Canada. Systematic Reviews, 4(1), 138.

Goetz, K., Jossen, M., Szecsenyi, J., Rosemann, T., Hahn, K., \& Hess, S. (2016). Job satisfaction of primary care physicians in Switzerland: an observational study. Family practice, 33(5), 498503.

González, P., \& Macho-Stadler, I. (2013). A theoretical approach to dual practice regulations in the health sector. Journal of health economics, 32(1), 66-87.

Gonzalez, P., Montes-Rojas, G., \& Pal, S. (2018). Dual Practice of Health Workers: Theory and Evidence from Indonesia. Available at SSRN 2975485.

Gray, M. (2019). How Australian dual registrants identified as midwives to meet national registrationrenewal requirements. Women and Birth, 32(1), 50-57.

Hackman, J. R., \& Oldham, G. R. (1976). Motivation through the design of work: Test of a theory. Organisational behavior and human performance, 16(2), 250-279.

Hart, O., \& Holmström, B. (1987). The theory of contracts. In Advances in economic theory: Fifth world congress (Vol. 1). Cambridge: Cambridge University Press.

Herzberg, F., Snyderman, B. B., \& Mausner, B. (1966). The motivation to work: 2d Ed. J. Wiley.

Hipgrave, D., Nachtnebel, M., \& Hort, K. (2013). Dual practice by health workers in South and East Asia: impacts and policy options. Policy brief, 2(1), 1-33.

Hirsch, B. T., Husain, M. M., \& Winters, J. V. (2016). Multiple job holding, local labor markets, and the business cycle. IZA Journal of Labor Economics, 5(1), 1-29.

Chen, H., Li, M., Dai, Z., Deng, Q., \& Zhang, L. (2016). Factors influencing the perception of medical staff and outpatients of dual practice in Shanghai, People's Republic of China. Patient Preference and Adherence, 10, 1667.

Islam, R., \& Ismail, A. Z. H. (2008). Employee motivation: a Malaysian perspective. International Journal of Commerce and Management.

Jansen, R. J., Sawyer, B. D., van Egmond, R., de Ridder, H., \& Hancock, P. A. (2016). Hysteresis in mental workload and task performance: the influence of demand transitions and task prioritisation. Human factors, 58(8), 1143-1157.

Jensen, M. C., \& Meckling, W. H. (1976). Theory of the firm: Managerial behavior, agency costs and ownership structure. Journal of Financial Economics, 3(4), 305-360.

Jiang, H., Pang, Z., \& Savin, S. (2012). Performance-based contracts for outpatient medical services. Manufacturing \& Service Operations Management, 14(4), 654-669.

Johannessen, K. A., \& Hagen, T. P. (2014). Physicians' engagement in dual practices and the effects on labor supply in public hospitals: Results from a register-based study. BMC Health Services Research, 14(1), 1-11. 
Kalb, G., Kuehnle, D., Scott, A., Cheng, T. C., \& Jeon, S. H. (2018). What factors affect physicians' labour supply: Comparing structural discrete choice and reduced-form approaches. Health economics, 27(2), e101-e119.

Kantarevic, J., \& Kralj, B. (2016). Physician payment contracts in the presence of moral hazard and adverse selection: the theory and its application in Ontario. Health Economics, 25(10), 13261340.

Karakolias, S., Kastanioti, C., Theodorou, M., \& Polyzos, N. (2017). Primary care doctors' assessment of and preferences on their remuneration: Evidence from greek public sector. INQUIRY: The Journal of Health Care Organization, Provision, and Financing, 54, 0046958017692274.

Keynes, J. M. (1937). The general theory of employment. The Quarterly Journal of Economics, 51(2), 209-223.

Kiwanuka, S. N., Rutebemberwa, E., Nalwadda, C., Okui, O., Ssengooba, F., Kinengyere, A. A., \& Pariyo, G. W. (2011). Interventions to manage dual practice among health workers. Cochrane Database of Systematic Reviews, (7).

Kottwitz, M. U., Hünefeld, L., Frank, B. P., \& Otto, K. (2017). The more, the better?! multiple vs. single jobholders' job satisfaction as a matter of lacked information. Frontiers in Psychology, 8, 1274.

Kusi, G. (2018). Moonlighting to Survive: The Effect of Multiple Job Holding on the Working Poor in Ghana (Doctoral dissertation, University of Ghana).

Lambrou, P., Kontodimopoulos, N., \& Niakas, D. (2010). Motivation and job satisfaction among medical and nursing staff in a Cyprus public general hospital. Human Resources for Health, 8(1), 26.

Locke, E. A. (1976). The nature and causes of job satisfaction. Handbook of Industrial and Organisational Psychology. Chicago: Rand McNally.

Martinez, A. Jr., Western, M., Haynes, M., Tomaszewski, W., \& Macarayan, E. (2014). Multiple job holding and income mobility in Indonesia. Research in Social Stratification and Mobility, 37, 91-104.

Marx, K. (1972). The Marx-Engels Reader (Vol. 4). New York: Norton.

Maslow, A. H. (1943). A theory of human motivation. Psychological Review, 50(4), 370.

Mbindyo, P. M., Blaauw, D., Gilson, L., \& English, M. (2009). Developing a tool to measure health worker motivation in district hospitals in Kenya. Human resources for health, 7(1), 1-11.

McClelland, D. C. (1965). Toward a theory of motive acquisition. American Psychologist, 20(5), 321.

Miotto, B. A., Guilloux, A. G. A., Cassenote, A. J. F., Mainardi, G. M., Russo, G., \& Scheffer, M. C. (2018). physician's sociodemographic profile and distribution across public and private health care: an insight into physicians' dual practice in Brazil. BMC health services research, 18(1), 1-10.

Mitnick, B. M. (1975). The theory of agency. Public Choice, 24(1), 27-42.

Mobley, W. H. (1977). Intermediate linkages in the relationship between job satisfaction and employee turnover. Journal of Applied Psychology, 62(2), 237.

Moghri, J., Mohammad, A. R. A. B., Rashidian, A., \& Sari, A. A. (2016). Physician dual practice: a descriptive mapping review of literature. Iranian journal of public health, 45(3), 278.

Mossialos, E., Allin, S., \& Davaki, K. (2005). Analysing the Greek health system: a tale of fragmentation and inertia. Health economics, 14(S1), S151-S168.

Ojakaa, D., Olango, S., \& Jarvis, J. (2014). Factors affecting motivation and retention of primary health care workers in three disparate regions in Kenya. Human resources for health, 12(1), 1-13. 
Paez, A. (2017). Gray literature: An important resource in systematic reviews. Journal of Evidence-Based Medicine, 10(3), 233-240.

Paina, L., Bennett, S., Ssengooba, F., \& Peters, D. H. (2014). Advancing the application of systems thinking in health: exploring dual practice and its management in Kampala, Uganda. Health research policy and systems, 12(1), 1-14.

Panos, G. A., Pouliakas, K., \& Zangelidis, A. (2014). Multiple job holding, skill diversification, and mobility. Industrial Relations: A Journal of Economy and Society, 53(2), 223-272.

Purcell, N. L., Goldman, J. G., Ouyang, B., Bernard, B., \& O'Keefe, J. A. (2019). The effects of dual-task cognitive interference and environmental challenges on balance in Huntington's disease. Movement disorders clinical practice, 6(3), 202-212.

Riley, S. (2005). Herzberg's two-factor theory of motivation applied to the motivational techniques within financial institutions.

Ross, S. A. (1973). The economic theory of agency: The principal's problem. The American Economic Review, 63(2), 134-139.

Russo, G., Fronteira, I., Jesus, T. S., \& Buchan, J. (2018). Understanding nurses' dual practice: a scoping review of what we know and what we still need to ask on nurses holding multiple jobs. Human resources for health, 16(1), 1-16.

Russo, G., McPake, B., Fronteira, I., \& Ferrinho, P. (2013). Negotiating markets for health: an exploration of physicians' engagement in dual practice in three African capital cities. Health Policy and Planning, 29(6), 774-783.

Socha, K. Z., \& Bech, M. (2011). Physician dual practice: a review of literature. Health Policy, 102(1), 17.

Spector, P. E. (1997). Job satisfaction: Application, assessment, causes, and consequences (Vol. 3). SAGE Publications.

Strouwen, C., Molenaar, E. A., Münks, L., Broeder, S., Ginis, P., Bloem, B. R., ... \& Heremans, E. (2019). Determinants of dual-task training effect size in Parkinson disease: who will benefit most?. Journal of Neurologic Physical Therapy, 43(1), 3-11.

Wombacher, J. C., \& Felfe, J. (2017). Dual commitment in the organisation: Effects of the interplay of team and organisational commitment on employee citizenship behavior, efficacy beliefs, and turnover intentions. Journal of Vocational Behavior, 102, 1-14.

Yusoff, W. F. W., Kian, T. S., \& Idris, M. T. M. (2013). Herzberg's two factors theory on work motivation: does its work for today's environment. Global Journal of Commerce and Management, 2(5), 1822.

The research paper passed the review process. | Received: June 3, 2020; Revised: December 13, 2020; Accepted: January 6, 2021; Pre-published online: May 3, 2021; Published in the regular issue: December 6, 2021 


\section{Appendix}

\section{Table A1 | Synthesis}

\begin{tabular}{|c|c|c|c|c|c|c|}
\hline \multicolumn{2}{|c|}{ Study details and design } & \multirow{2}{*}{$\begin{array}{l}\text { Key words } \\
\\
\text { Physician, } \\
\text { Dual practice, } \\
\text { Moonlight, } \\
\text { Review, } \\
\text { Descriptive } \\
\text { mapping } \\
\end{array}$} & \multirow{2}{*}{$\begin{array}{l}\text { Variables } \\
\text { Motivation and } \\
\text { forces behind } \\
\text { dual practice; } \\
\text { consequences } \\
\text { of dual } \\
\text { practice; dual } \\
\text { practice } \\
\text { policies and } \\
\text { their impact } \\
\end{array}$} & \multirow{2}{*}{$\begin{array}{l}\begin{array}{l}\text { Research } \\
\text { methods }\end{array} \\
\\
\text { Descriptive } \\
\text { mapping } \\
\text { review } \\
\text { methods }\end{array}$} & \multirow{2}{*}{$\begin{array}{l}\begin{array}{l}\text { Data } \\
\text { mining }\end{array} \\
\\
\text { Main papers } \\
\text { and } \\
\text { documents } \\
\text { in the field of } \\
\text { physician } \\
\text { dual } \\
\text { practice. }\end{array}$} & \multirow{2}{*}{$\begin{array}{l}\text { Novelty (findings) } \\
\text { Findings showed a dearth of scientifically } \\
\text { reliable literature in some areas of dual } \\
\text { practice, like the prevalence of the } \\
\text { phenomenon, the real consequences of it, } \\
\text { and the impacts of the implemented policy } \\
\text { measures. }\end{array}$} \\
\hline $\begin{array}{l}\text { Moghri, } \\
\text { Mohammad, A., } \\
\text { R. A. B., } \\
\text { Rashidian, A., \& } \\
\text { Sari, A. A. (2016) } \\
\end{array}$ & $\begin{array}{l}\text { Physician Dual } \\
\text { Practice: A } \\
\text { Descriptive } \\
\text { Mapping } \\
\text { Review of } \\
\text { Literature } \\
\end{array}$ & & & & & \\
\hline $\begin{array}{l}\text { Abera, G. G., } \\
\text { Alemayehu, Y. } \\
\text { K., \& Herrin, J. } \\
(2017)\end{array}$ & $\begin{array}{l}\text { Public-on- } \\
\text { private dual } \\
\text { practice among } \\
\text { physicians in } \\
\text { public hospitals } \\
\text { of Tigray } \\
\text { National } \\
\text { Regional State, } \\
\text { North Ethiopia: } \\
\text { perspectives of } \\
\text { physicians, } \\
\text { patients and } \\
\text { managers }\end{array}$ & $\begin{array}{l}\text { Circular } \\
\text { diversion } \\
\text { pattern, health } \\
\text { worker } \\
\text { retention, dual } \\
\text { practice ban, } \\
\text { dual practice }\end{array}$ & $\begin{array}{l}\text { Circular } \\
\text { diversion } \\
\text { pattern, health } \\
\text { worker } \\
\text { retention, dual } \\
\text { practice ban, } \\
\text { dual practice } \\
\end{array}$ & $\begin{array}{l}\text { A cross- } \\
\text { sectional study } \\
\text { using mixed } \\
\text { methods }\end{array}$ & $\begin{array}{l}\text { Primary } \\
\text { data from } \\
\text { semi- } \\
\text { structured } \\
\text { and } \\
\text { structured } \\
\text { questionnair } \\
\text { es }\end{array}$ & $\begin{array}{l}\text { Circular diversion pattern of referral } \\
\text { system is the key negative consequence } \\
\text { of dual practice. Physicians and hospital } \\
\text { managers agreed that health worker } \\
\text { retention was the main positive } \\
\text { consequence of dual practice upon the } \\
\text { public sector, and banning dual practice } \\
\text { would result in a major loss of senior } \\
\text { physicians. }\end{array}$ \\
\hline 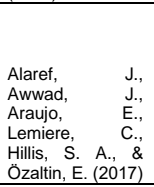 & $\begin{array}{l}\text { To Ban or Not } \\
\text { to Ban? } \\
\text { Regulating } \\
\text { Dual Practice } \\
\text { in Palestine } \\
\end{array}$ & $\begin{array}{l}\text { dual } \\
\text { practice, health } \\
\text { markets, monit } \\
\text { oring and } \\
\text { accountability, } \\
\text { Palestine, priv } \\
\text { ate } \\
\text { sector, quality } \\
\text { of care } \\
\end{array}$ & $\begin{array}{l}\text { policy's } \\
\text { enforceability, } \\
\text { implications, } \\
\text { and } \\
\text { sustainability of } \\
\text { dual practice } \\
\end{array}$ & & $\begin{array}{l}\text { Primary and } \\
\text { secondary } \\
\text { data }\end{array}$ & $\begin{array}{l}\text { Study found that an outright ban on dual } \\
\text { practice would not reduce the financial } \\
\text { burden on patients and enhance their } \\
\text { access to quality services in the public } \\
\text { sector. }\end{array}$ \\
\hline $\begin{array}{lr}\text { Bazyar, } & \text { M., } \\
\text { Rashidian, } & \text { A., } \\
\text { Jahanmehr, } & \text { N., } \\
\text { Behzadi, } & \text { F., } \\
\text { Moghri, J., } & \& \\
\text { Doshmangir, } & \text { L. } \\
\text { (2018). } & \\
\end{array}$ & $\begin{array}{l}\text { Prohibiting } \\
\text { physicians' } \\
\text { dual practice in } \\
\text { Iran: Policy } \\
\text { options for } \\
\text { implementation }\end{array}$ & $\begin{array}{l}\text { Physician Dual } \\
\text { Practice, Policy } \\
\text { Options, Iran, } \\
\text { Dual-Job } \\
\text { Holding }\end{array}$ & $\begin{array}{l}\text { Policy Options, } \\
\text { Physician Dual } \\
\text { Practice }\end{array}$ & $\begin{array}{l}\text { International } \\
\text { evidence } \\
\text { published in } \\
\text { English and } \\
\text { local } \\
\text { documents } \\
\text { published }\end{array}$ & $\begin{array}{l}\text { Not } \\
\text { indicated }\end{array}$ & $\begin{array}{l}\text { No single optimal PO exists for dealing } \\
\text { with the dual practice in Iranian health } \\
\text { system. }\end{array}$ \\
\hline $\begin{array}{l}\text { Chen, H., Li, M., } \\
\text { Dai, Z., Deng, Q., } \\
\text { \& Zhang, L. } \\
(2016) .\end{array}$ & $\begin{array}{l}\text { Factors } \\
\text { influencing the } \\
\text { perception of } \\
\text { medical staff } \\
\text { and outpatients } \\
\text { of dual practice } \\
\text { in Shanghai, } \\
\text { People's } \\
\text { republic of } \\
\text { china. } \\
\end{array}$ & $\begin{array}{l}\text { dual practice, } \\
\text { perception of } \\
\text { medical staff, } \\
\text { outpatients' } \\
\text { perception, } \\
\text { influential } \\
\text { factors, labor } \\
\text { supply } \\
\end{array}$ & $\begin{array}{l}\text { Dual Practice, } \\
\text { Perception of } \\
\text { medical staff, } \\
\text { Outpaticients' } \\
\text { Perception, } \\
\end{array}$ & $\begin{array}{lr}\text { A ross- } \\
\text { sectional study }\end{array}$ & $\begin{array}{l}\text { Questionnai } \\
\text { res }\end{array}$ & $\begin{array}{l}\text { This study confirmed that both medical } \\
\text { staff and outpatients generally held } \\
\text { positive attitudes toward dual practice }\end{array}$ \\
\hline $\begin{array}{l}\text { Kreindler, S. A., } \\
\text { Larson, B. K., } \\
\text { Wu, F. M., } \\
\text { Gbemudu, J. N., } \\
\text { Carluzzo, K. L., } \\
\text { Struthers, A., ... \& } \\
\begin{array}{l}\text { Fisher, E. S. } \\
(2014) .\end{array}\end{array}$ & $\begin{array}{l}\text { The rules of } \\
\text { engagement: } \\
\text { physician } \\
\text { engagement } \\
\text { strategies in } \\
\text { intergroup } \\
\text { contexts. }\end{array}$ & $\begin{array}{l}\text { Mangers, } \\
\text { qualitative } \\
\text { research, } \\
\text { change } \\
\text { mananegemen } \\
\text { t, USA, social } \\
\text { identification } \\
\text { and doctors }\end{array}$ & & $\begin{array}{l}\text { Qualitative } \\
\text { methods }\end{array}$ & $\begin{array}{l}109 \\
\text { managers } \\
\text { and } \\
\text { physicians }\end{array}$ & $\begin{array}{l}\text { Beyond a universal focus on relationship- } \\
\text { building, sites differed radically in their } \\
\text { preferred strategies. Each emphasised or } \\
\text { downplayed professional and/or } \\
\text { organisational identity as befit the existing } \\
\text { level of inter-group closeness between } \\
\text { physicians and managers: an } \\
\text { independent practice association sought } \\
\text { to enhance members' identity as as } \\
\text { independent physicians; a hospital, ans } \\
\text { engaging community physicians } \\
\text { suspicious of integration, stressed } \\
\text { collaboration among separate, equal } \\
\text { partners; a developing integrated-delivery } \\
\text { system promoted alignment among } \\
\text { diverse groups by balancing "stemness" } \\
\text { with subgroup uniqueness; a medical } \\
\text { group established a strong common } \\
\text { identity among employed physicians, but } \\
\text { practised pragmatic co-operation with its } \\
\text { affiliates }\end{array}$ \\
\hline
\end{tabular}

Source: authors 